\title{
HISTOPATHOLOGICAL SIDE EFFECTS OF NORISTERAT ON ADRENAL - PITUTARY AXIS IN MALE AND FEMALE PALM SQUIRREL FUNAMBULUS PENNANT (WROUGHTON)
}

\author{
Ganvir K.S. \\ L.A.D. College for Women, Nagpur \\ Email : karunaganvir9890@gmail.com
}

\begin{abstract}
:
Norethisterone (NET) a synthetic progestogen contraceptive is one of the derivatives of 19-Nortestosterone widely wed in gynaecological disorders and in oral contraceptive pills for women such as Mala-D, Mala-N etc. This contraceptive inhibits ovulation due to suppression of GnRH \& pituitary gonadotrophins FSH \& LH. It has also been demonstrated that NET-En and other derivatives of 19-nortestosterone suppress spermatogenesis in laboratory animals \& men. Synthetic progestogens impair libido, potency \& functions of sex accessory gloands. Therefore, male fertility regulation with progestin demands additional substitute with androgen. It is also noted that considerable disagreement exists regarding the action of NET-En on anterior pituitary cell types. Perusal of literature has revealed that in the past, investigators have studied action of Noristerate on testis-pituitary axis and ovary-pituitary axis ignoring its side effects on Adrenal-Pituitary axis. It was with this point of view in mind that Noristerate has been selected to study the side effects of this drug or Adrenal-Pituitary axis and its mechanism of action. The experiments were conducted on both male and female palm squirrel during July-August i.e. at the end of breeding season. Male squirrels of experimental group received $4 \mathrm{mg} / \mathrm{kg}$ B.W. Single intramuscular injection and sacrificed after 2 months. Female squirrels of experimental group received 0.5 $\mathrm{mg} / \mathrm{kg}$ B.W./Week for 1 month. Experimental male adrenal showed no significant changes in the cells of zona glomerulosa and induce hypertrophy of zona fasiculata and zona reticularis cells. Zona medullary cells showed regressive changes such as presence of vacuoles and pycnosis of nuclei. At $0.5 \mathrm{mg}$ Noristerat for one month treatment, female adrenal showed no changes in zona glomerulosa. Cells of zona fasciculata showed hypertrophy, hyperplasia and degranulation after the treatment. Cells of zona reticularis showed vacuolization \& cells of medulla showed degranulation. ACTH cells of anterior pituitary of male and female squirrel showed similar changes i.e. hypertrophy \& hyperplasia after the treatment. Histopathological side effects of Noristerat on adrenal (hyperactivity) appears to be via pituitary gland since ACTH showed hyperactivity after the treatment.
\end{abstract}

Key words: - Adrenal-Pituitary axis, Noristerat.

\section{INTRODUCTION}

In the present study Noristerat (Norethisterone NET-En Enanthate), a synthetic progestogen was used. Norethisterone (NET) a synthetic progestogen contraceptive is one of the derivatives of 19Nortestosterone, widely used in gynaecological disorders and in oral contraceptive pills for women such as Mala-D, Mala-N etc. It is fully reversible. This contraceptive inhibits ovulation due to suppression of GnRH \& Pituitary gonadotrophins FSH and LH (Greenwald, 1965, Faundes et al 1991, Emones et al 1992). On the basis of Pharmacological-Endocrinological background, these compounds have been used for fertility control in female. Noristerat has multiple site of action. It has also been demonstrated that NET-En and other derivatives of 19-nortestosterone suppress spermatogenesis in laboratory animals and men (Terner and Maclaughtlin 1973, Schurmeyer et al 1984(a) and Das 1989). Synthetic progestogens impair libido, potency and functions of sex accessory glands. Therefore, male fertility regulation with progestin demands additional substitute with androgen. Considerable disagreement exists regarding the action of NET-En on anterior pituitary cell types. In the present investigation efforts were made to examine the side effects of this drug on adrenal-pituitary axis and its mechanism of action.

\section{MATERIAL AND METHODS :-}

Noristerat contain norethisterone enanthate (NETEn) a derivative of 19-nortestosterone. The drug was purchased from the local Chemist 
(manufactured by Schering AG Berlin, Germany). The Noristerat has been accepted as a contraceptive for women and it is also found to suppress spermatogenesis. The experiments were conducted on both male and female palm squirrel during July-August i.e. at the end of breeding season. The detail experimental design, grouping and protocol given is the Table 1 . Male squirrel of experimental group received $4 \mathrm{mg} / \mathrm{kg}$. B.W. single intramuscular injection and sacrificed after 2 months. Female squirrels of experimental group received $0.5 \mathrm{mg} / \mathrm{kg}$. B.W./week for 1 month. Noristerat was diluted in arachis oil and control received equivalent volume of vehicle.

\section{RESULT \& DISCUSSION}

\section{Adrenal of Control Male (Dia-1)}

The cells of zona glomerulosa $(\mathrm{ZG})$ were arranged in clusters. The cells were round or polygonal with full secretary granules. However, few vacuolated cells were also seen occasionally. The cells of zona fasciculata were arranged in cords. They were enlarged, thickly granulated with conspicuous nuclei. The cells were cuboidal or oval in shape. The cells of zona reticularis are compactly arranged and the cell wall was fused. The cells contained vacuoles giving foamy appearance. The zone is clearly demarcated from medullary zone.

Zona Medulla was well vasculorised and composed of two cell types. Type A cells were large in size, plenty and other cell types were few and irregular in shape with indistinct nuclei. Cytoplasmic granules were thick. Vacuoles were also noticed in the cyloplasm of type A cells.

\section{Adrenal of Experimental Male (Dia-2)}

Two months after $4 \mathrm{mg}$ Noristerat treatment adrenal showed no significant changes in the cells of zona glomerulosa and induce hypertrophy of zona fasciculata and zona reticularis cells. Zona medullary cells showed regressive changes such as presence of vacuoles and pycnosis of nuclei.

\section{Adrenal of control Female (Dia-4)}

Histological structure of adrenal of female is similar to adrenal of male.

\section{Adrenal of Experimental Female (Dia 3\&5)}

At $0.5 \mathrm{mg}$. Noristerat for one month treatment showed no changes in zona glomerulosa. Cells of zona fasciculata showed hypertrophy, hyperplasia and degranulation after the treatment. Cells of zona reticularis showed vacuolization and cells of medulla showed degranulation.

Anterior pituitary of control Male \& Female Showing normal ACTH cells (Dia 6 \& 8).

\section{Anterior pituitary of Experimental Male \& Female (Dia 7\&9)}

Two months after the single dose of Noristerat (4 $\mathrm{mg} / \mathrm{kg}$ ) treatment to male ACTH cells showed hypertrophy and hyperplasia after the treatment.

Female squirrel administered with Noristerat (0.5 $\mathrm{mg} / \mathrm{kg}$ B.W./Week for one month) showed similar changes in the cells of anterior pituitary gland as compared with those of Noristerat treated male.

The present study on adrenal pituitary axis indicates that Noristerat induced hypertrophy in zona fasciculata and zona reticularis in male and hypertrophy, hyperplasia and degranulation in zona fasciculata in adrenal of female squirrel.

It appears that in squirrel Noristerat act on ACTH of anterior pituitary cells which produce more corticotrophic hormone, consequently zona reticularis produce more corticosteroid.

On the other hand other investigators reported that synthetic progestogen inhibit ACTH cells of the pituitary and regressed adrenal cortex (Givner and Rochefort, 1972; and Mischell, 1974).

\section{Mechanism of Action of Noristerat}

Histopathological side effects of Noristerat on adrenal (hyperactivity) appears to be via pituitary gland since ACTH cells showed hyperactivity after the treatment.

\section{Conclusion}

Noristerat produce hypertrophy of adrenal cortex via anterior pituitary.

\section{REFERENCES:-}

Das, R.P. (1989). Contraceptive technology pastpresent and future. Published by NIHFW, New Delhi. Status Reports Series-1 pg. 37-48.

Emons, G., Nill, J.; Sturm, R. and Ortmann, O. (1992) Effects of progesterone one gonadotropin releasing hormone receptor concentration in cultured estrogen primed female rat pituitary cells. J. Steroid Biochem Mol Biol 42 (8): 831839.

Faundes, A.; Brache, V.; Tejada, A.S. (1991). Ovulatory dysfunction during continuous administration of low-dose levonorgestrel by subdermal implants. Fertility and sterility 56(1):27.

Givner, M.L. and Rochefort, J.G. (1972). Effects of synthetic progestogens and Estradiol-17 $\square$ on adrenal function in the rat. Endocrinology 90: 1238-1244. 
Greenwald, G.S. (1965). The effects of single injection of diethylstilboestrel or progesterone on the hamster ovary. J. Endocrin. 33:13-23.

Mischell, D.R. (1974). Progress report : DMPA for contraception Obstet Gynecol 3:15-17.

Schurmeyer, T.H.; Knuth, V.A.; Belkien, L. and Nieschlag, E. (1984a). Reversible azoospermia induced by the anabolic steroid 19nortestosterone. Lancet i:417.

Solcia et al (1969). Lead haematoxylin as a stain for endocrine cells. Significance of staining and comparison with other selective methods. Histochemic 20:116-126.

Terner, C. and Maclaughtlin, J. (1973). J. Reprod. Fert. 32:458.

Table 1 : Experimental design for Noristerat

\begin{tabular}{|c|c|c|c|c|}
\hline $\begin{array}{c}\text { No. of Animals \& } \\
\text { Sex }\end{array}$ & Treatment & $\begin{array}{c}\text { Dose / } \\
\mathbf{m g} / \mathbf{k g} \\
\mathbf{B . w} .\end{array}$ & Administration & $\begin{array}{c}\text { Duration } \\
\text { (months) }\end{array}$ \\
\hline $\begin{array}{c}\text { 10 Males } \\
\text { (Experimental) }\end{array}$ & Noristerat & $\begin{array}{c}4 \mathrm{mg} \text { single } \\
\text { dose }\end{array}$ & I.M. & 2 \\
\hline 10 Males (control) & $\begin{array}{c}\text { Arachis oil } \\
\text { (Vehicle) }\end{array}$ & $\begin{array}{c}\text { E.V. }(0.1 \\
\mathrm{ml})\end{array}$ & I.M. & 2 \\
\hline $\begin{array}{c}\text { 10 Females } \\
\text { Experimental) }\end{array}$ & Noristerat & $\begin{array}{c}0.5 \\
\mathrm{mg} / \mathrm{week}\end{array}$ & I.M. & 1 \\
\hline $\begin{array}{c}\text { 10 Females } \\
\text { (Control) }\end{array}$ & Vehicle & $\begin{array}{c}\mathrm{E} . \mathrm{V} .(0.1 \\
\mathrm{ml})\end{array}$ & I.M. & 1 \\
\hline
\end{tabular}

E.V. = Equivalent volume, I.M. = Intramuscular (injection)

Table 2 : Cell types of Anterior Pituitary and their Tinctorial Properties

\begin{tabular}{|c|c|c|c|c|c|c|}
\hline $\begin{array}{c}\text { Staining } \\
\text { Techniques }\end{array}$ & $\begin{array}{c}\text { Type I } \\
\text { GH }\end{array}$ & $\begin{array}{c}\text { Type II } \\
\text { PRL }\end{array}$ & $\begin{array}{c}\text { Type III } \\
\text { TSH }\end{array}$ & $\begin{array}{c}\text { Type IV } \\
\text { FSH }\end{array}$ & $\begin{array}{c}\text { Type V } \\
\text { LH/ } \\
\text { ICSH }\end{array}$ & $\begin{array}{c}\text { Type VI } \\
\text { ACTH }\end{array}$ \\
\hline $\begin{array}{c}\text { Solcia et al } \\
\text { (1969) } \\
\begin{array}{c}\text { PbH(Lead } \\
\text { Haematoxylin) }\end{array}\end{array}$ & - & - & - & - & - & Black \\
\hline
\end{tabular}




\section{Plate-I}

Effects of Noristerat on Adrenal gland of Funambulus pennant

Fig. 1-5 Sections stained with Haematoxylin \& Eosin

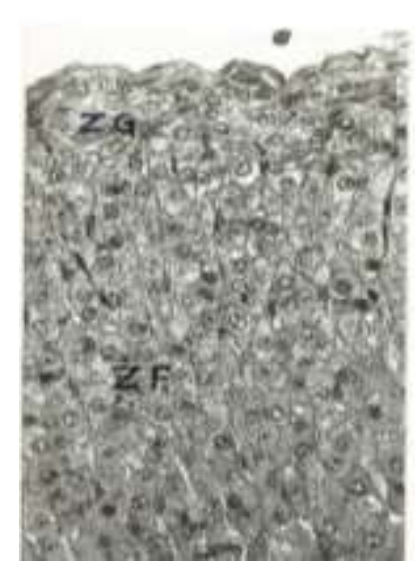

Fig. 1 : Control male Adrenal gland showing normal cylological details $(\times 290)$

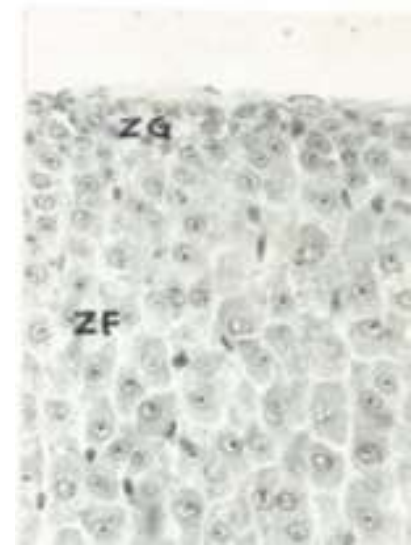

Fig. 2 : Experimental Male Adrenal showing hypertrophy of zona fasciculata cells, No changes in zona glome rulosa $(\times 290)$

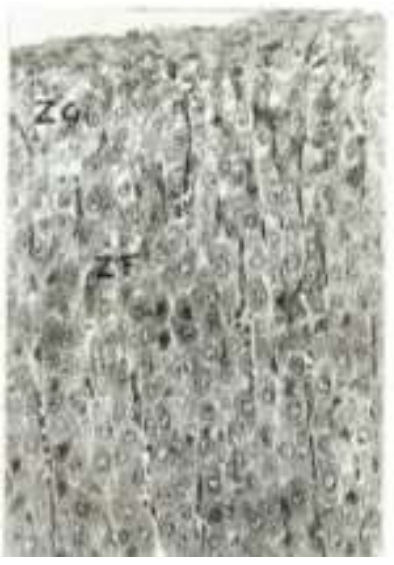

Fig. 3 : Experimental Female Adrenal showing No changes of zona glomerulosa and hypertrophy, hyperplasia and degranulation in zona fasciculate $(\times 290)$

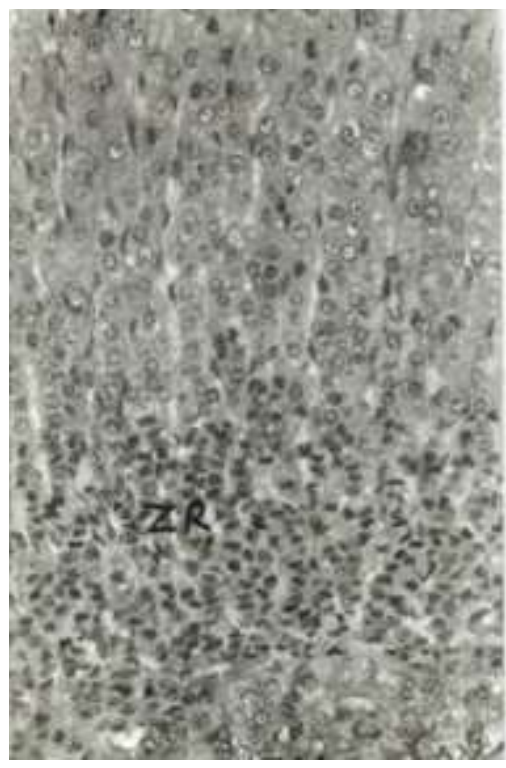

Fig. 4 : Control Female Adrenal showing various zones \& its cytological details $(\times 290)$

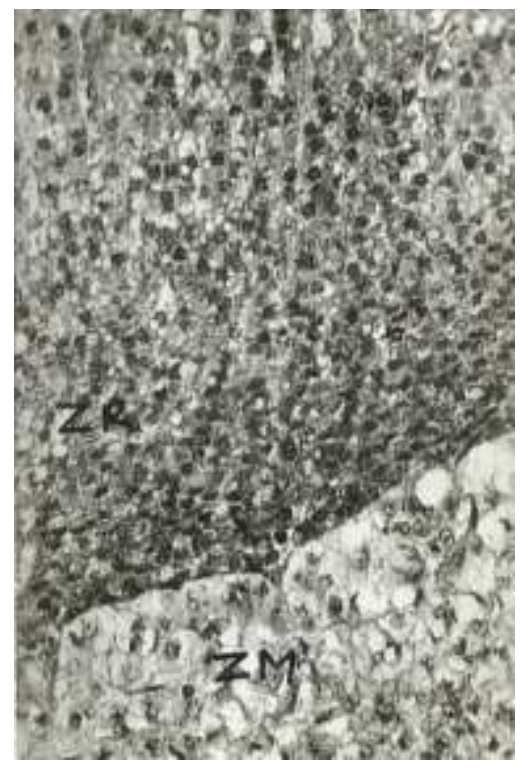

Fig. 5 : Experimental Female Zona reticularis \& zona medulla of adrenal showing intense vacuolization in cells of zona reticularis and degranulation in the cells of zona medulla $(\times 290)$ 
Plate-II

Effects of Noristerat on Anterior pituitary gland.

Fig. 6 to 9 sections are stained with lead Haematoxylin $(\mathrm{PbH})(\times 900)$

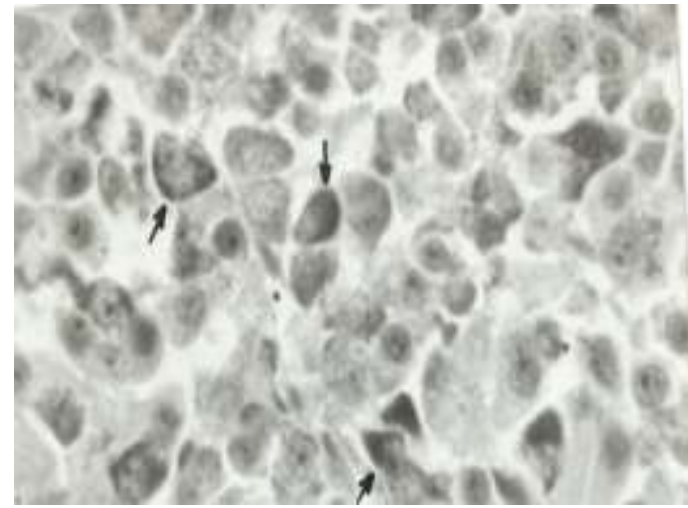

Fig. 6 : Control male Anterior pituitary showing normal ACTH (PbH +ve black) cells

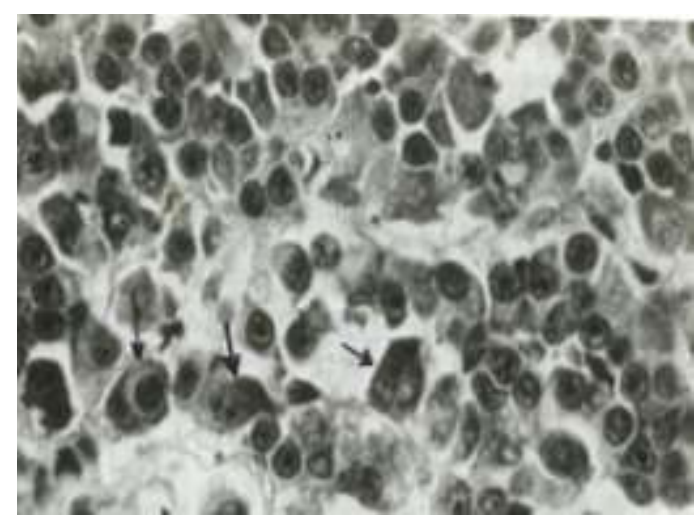

Fig. 8 : Control Female Anterior pituitary showing normal ACTH cells (indicated by arrow)

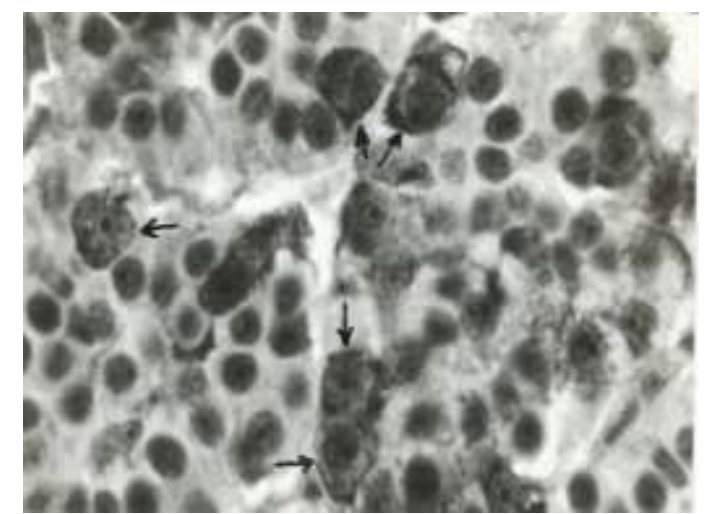

Fig. 7 : Experimental male Anterior pituitary showing hypertrophy $\&$ hyperplasia of ACTH ( $\mathrm{PbH}+$ ve black) cells

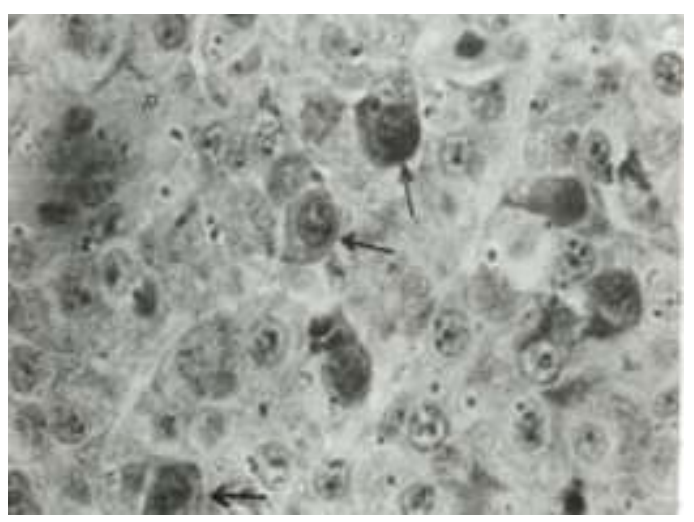

Fig. 9 : Experimental Female Anterior pituitary showing hypertrophy \& hyperplacia of ACTH cells (indicated by arrow) 